\section{The Performance Evaluation of State Grassland Ecological Compensation and Rewards-A Case Study in Yili, Xinjiang, China} China

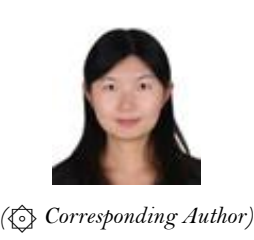

\author{
(D) $\operatorname{Dan} \mathbf{L i}^{1+8}$ \\ (D) Fengqin $\mathrm{Han}^{2}$ \\ ${ }^{1,2}$ Chinese Academy of Fiscal Sciences, Beijing, China. \\ Email:lidan0617@live.com Tel: 8613718627716 \\ [Email: mofhfq@,163.com Tel: 8601088191703
}

International Journal of Economics, Business and Management Studies Vol. 8, No. 2, 38-50, 2021 e-ISSN: 2226-4809/p-ISSN: 2304-6945

check for
updates

\title{
ABSTRACT
}

Since 2011, the State Grassland Ecological Compensation and Rewards(GECR) had implemented in 13 provinces (regions) in China. This policy controlled livestock carrying capacity on pasture and provided subsidies to pastoralists, aimed at reducing livestock number on grassland, increasing income of pastoralist households, and restoring degraded grassland ecosystem. Taking Nileke County of Xinjiang, China as a case study, this research evaluated the ecological, economic and social performance of GECR in agro-pastoral area. Using annual series data during 2006-2010 and 20112015, the change of grassland ecological condition, household living standard and labor population was compared between the two periods, and the influence of GECR were validated and detailed with semi-structured household interviews. The results showed that after 2011, livestock number in pastoral area decreased. In contract, the livestock in agricultural area showed large growth. Farmers' livestock use pasture through grazing transaction, which means farmers paid herders to graze their livestock on the herder's pasture. Widespread transactions between farmers and herders led to overgrazing on pasture and grassland degradation. GECR also had no significant contribution on improving household income and encouraging livelihood transition. The policy had no significant benefits in ecology, economy and society in case area. Based on the findings, we put forwards suggestions from three aspects: improving the design of the GECR policy, establishing performance evaluation system, strengthening the supervision and punishment of grassland overgrazing and improving local human capital quality .

Keywords: State grassland ecological compensation and rewards(GECR), Performance evaluation, Grassland ecological condition, Livestock number, Household living standard, Labor population, Overgrazing. JEL: Q58.

DOI: $10.20448 / 802.82 .38 .50$

Citation | Dan Li; Fengqin Han (2021). The Performance Evaluation of State Grassland Ecological Compensation and Rewards-A Case Study in Yili, Xinjiang, China. International Journal of Economics, Business and Management Studies, 8(2): 38-50.

Copyright: This work is licensed under a Creative Commons Attribution 3.0 License

Funding: This study received no specific financial support.

Competing Interests: The authors declare that they have no competing interests.

History: Received: 29 October 2021/ Revised: 2 December 2021/ Accepted: 15 December 2021/ Published: 27 December 2021

Publisher: Online Science Publishing 


\section{Highlights of this paper}

- The performance evaluation of GECR was analyzed from ecological, economic and social aspects, and corresponding suggestions were proposed.

- The performance evaluation of GECR was analyzed based on annual statistic data combined with fieldwork results.

- The relationship between herders and farmers was described, explained why the policy were not effective in reducing pasture degradation.

\section{INTRODUCTION}

\subsection{Modern History of State Grassland Ecological Compensation and Rewards(GECR)}

Since 1990s, Chinese government has implemented a series of large-scale ecological projects in order to reduce grassland degradation and poverty in rural and pastoral areas in the western of China. In 2002, the State government issued a document refer to strengthening grassland protection and construction, which indicated the country pay more attention on grassland ecological issues related to natural resource, economic and social development. The document mentioned establishing temporary and permanent grazing ban in grassland areas, gradually changing the extensive grazing mode on grassland, pushing forward intensive way of livestock husbandry, developing high-yield artificial meadow and increasing forage production. "Central government will establish fund for grassland area." In the same year, the states modified the Grassland Law of China, set up a fund to reduce grazing on grassland and support intensive animal husbandry. In 2003, "Grazing Ban" Project was confirmed. The document of providing fund for fence construction and subsidies for pastoralists in grazing ban area was also published. By the end of 2010, the central government totally invested 1.8 billion USD on "Grazing Ban" Project, built fence on 51.9 million ha of grassland, and provide subsidies for almost 1 million households, more than 4.5 million pastoralists. In 2011, the State decided to change "Grazing Ban" Project into "Grassland Ecological Compensation and Rewards"(GECR) Project. 1.9 billion USD financial fund was provided for grazing ban compensation, livestock number control rewards, the production subsidies and other ecological protection work in 2011, and the investment amount increased year by year (Figure 1). According to the Grassland Law of China, the local grassland management department in county level decide the livestock grazing capacity standard of the grassland, based on the grazing capacity standard of different grassland types, combined with 5 years average yield of natural grassland, artificial meadow and forage land in this area. The livestock number of pastoralists households in county should not exceed the grazing capacity standard.

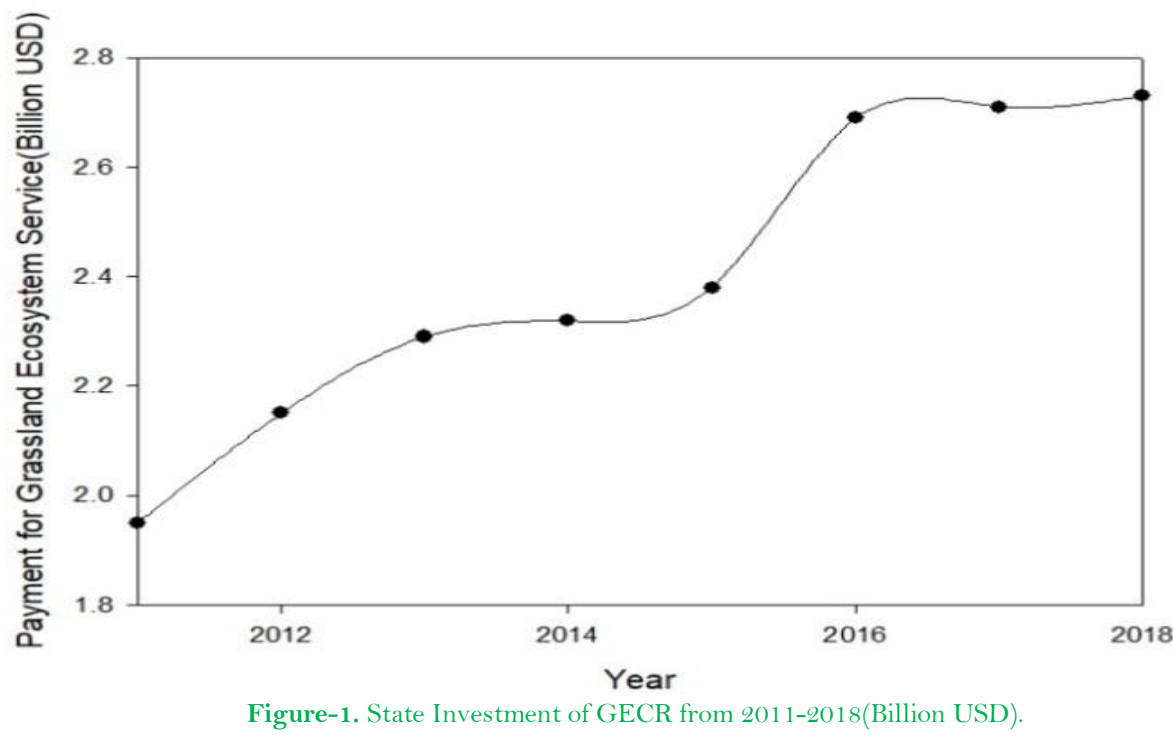


The local government controls the number of livestock based on grassland area and productivity. Before 2011, government did not provide subsidies for livestock number control. Since the GECR Project started, the pastoralists of 578 counties in 13 provinces and regions in China got subsidies in a form of "reward" for the control of livestock number.

\subsection{The Standard of GECR}

The standard of GECR was calculated according to the vegetation productivity of the grassland. The unit grass yield per year was converted into forage quantity, and then calculated according to the market price of the forage. The guidance of the standard of the compensation and rewards explained: 1) Grazing ban is still implemented in severe degradation grassland and grassland in river headwater area. The State provides a compensation of $12.75 \mathrm{USD} /$ ha per year for pastoralist households who cannot use their pasture. After 5 years, local government will check the ecological condition of grassland in grazing ban area and decide the grazing ban shall be continued or transfer to livestock number control. 2) Livestock carrying capacity control is implemented in grassland except the grazing ban area. The State provides a reward of $2.15 \mathrm{USD} / \mathrm{ha}$ for all the pastoralist households, to encourage them to reduce their livestock number and protect grassland. On the basis of the livestock number control, pastoralists also carry out seasonal rest of pasture and rotational grazing, forming a long-term mechanism of sustainable use of grassland. After one term of the GECR project from 2011 to 2015, the standard of the compensation and rewards raised to $16.05 \mathrm{USD} /$ ha for grazing ban compensation and 5.37 USD/ha for livestock number control rewards in 2016.

\subsection{The Performance Evaluation of GECR}

Several research focused on the performance evaluation of grassland ecological policy. Gu and Li evaluated the vegetation coverage and vegetation normalization index (NDVI) change in grazing ban area to show the ecological effect of the policy $(\mathrm{Gu} \& \mathrm{Li}, 2012 ; \mathrm{Li} \& \mathrm{Li}, 2012)$. Most of the research established a variety of evaluation index systems, including the implementation and management of the grassland ecological policy, the ecological benefit of the policy, livestock husbandry production development, living standard of household, herders awareness of grassland protection, ecological policy satisfaction etc (Fan, Ma, \& Yin, 2008; Li, 2006; Ma, Lu, \& Xing, 2006; Song et al., 2004). The performance evaluation of GECR can be divided into several aspects, such as ecological, economic and social performance. Hu, Liu, and Jin (2016); Li, Sun, and Zhang (2017) believed that the implementation time of GECR Policy was relatively short, so the grassland vegetation productivity had not make significant progress, but obvious benefit on economic and social aspects was achieved. The pastoralists' living standards improved a lot. In contract, Zhang (2016) claimed that the rewards standard is too low for households, and the GECR policy failed to realize the economic incentive effect as expected. And the problem of rapid growth of livestock number led to the excessive use of grassland resource. In addition, Dong and Liu (2009) found that the supervision cost of GECR Policy was high while the cost of overgrazing was low, and most pastoralists were not satisfied with the policy. The policy has promoted shift from natural grazing to intensive animal husbandry, but the forage supply to feed livestock in shelter has become a great problem (Chen, 2013; Jin, 2015; Li, Gong, \& Li, 2014). Most of the research was done in pastoral area, mainly in Inner Mongolia.

With the implementation of the GECR Policy, almost all of the payment was confirmed to reach every household. The central government also paid close attention on the performance of the policy. At the end of 2012, the Ministry of Agriculture and Ministry of Finance in China released the performance evaluation index system of GECR Policy. The index system included 4 parts: Policy making, Basic work, Effects and Illegal behavior (Table 1). 
The performance evaluation of the GECR was carried out strictly each year. On the basis of the evaluation results, the central government provided a total of 4.45 million USD of performance rewards to the provinces and regions that passed the evaluation and got high grades, promoted supports for the development of intensive animal husbandry.

Table-1. The Performance Evaluation Index System of GECR.

\begin{tabular}{|c|c|c|}
\hline Content & Index & Detailed Description \\
\hline \multirow[t]{3}{*}{ Policy making ( $15 \%$ ) } & $\begin{array}{l}\text { Management } \\
\text { construction }\end{array}$ & $\begin{array}{l}\text { Management system and related documents of } \\
\text { the policy }\end{array}$ \\
\hline & Implementation plan & Documents approved the plan and reports \\
\hline & $\begin{array}{l}\text { Supporting policies for the } \\
\text { rewards }\end{array}$ & $\begin{array}{l}\text { Documents of supporting policies and } \\
\text { allocation plan }\end{array}$ \\
\hline \multirow[t]{9}{*}{ Basic work ( $35 \%)$} & $\begin{array}{l}\text { Household Contract of the } \\
\text { grassland }\end{array}$ & $\begin{array}{l}\text { Ratio of Household Contract grassland area to } \\
\text { total grassland area }\end{array}$ \\
\hline & Basic grassland & $\begin{array}{l}\text { Ratio of basic grassland area to total } \\
\text { grassland area }\end{array}$ \\
\hline & $\begin{array}{l}\text { Grassland } \\
\text { monitoring }\end{array}$ & $\begin{array}{l}\text { Annual grassland ecological monitoring } \\
\text { reports }\end{array}$ \\
\hline & Grassland law enforcement & Rate of livestock reduction \\
\hline & Information system & $\begin{array}{l}\text { Filling the compensation and rewards } \\
\text { information system }\end{array}$ \\
\hline & Working procedure & $\begin{array}{l}\text { Signing the contract for grazing ban and } \\
\text { livestock number control with all the } \\
\text { households }\end{array}$ \\
\hline & Forage seed subsidy plan & $\begin{array}{l}\text { Documents of the free forage seeds allocation } \\
\text { plan }\end{array}$ \\
\hline & Technical training & $\begin{array}{l}\text { Technical training and policy promotion on } \\
\text { grazing ban and livestock number control }\end{array}$ \\
\hline & Monthly report & $\begin{array}{l}\text { Handing on report timely, accurate, rich in } \\
\text { content }\end{array}$ \\
\hline \multirow[t]{6}{*}{ Effects ( $50 \%)$} & Grazing ban & $\begin{array}{l}\text { Consistent with the implementation plan, } \\
\text { payment confirmed to reach every household }\end{array}$ \\
\hline & Livestock number control & $\begin{array}{l}\text { Consistent with the implementation plan, } \\
\text { payment confirmed to reach every household }\end{array}$ \\
\hline & Forage seed subsidy & Payment confirmed to reach every household \\
\hline & Production subsidies & Payment confirmed to reach every household \\
\hline & Performance evaluation & Carrying out the performance evaluation work \\
\hline & $\begin{array}{l}\text { Grassland } \\
\text { improvement }\end{array}$ & $\begin{array}{l}\text { Grassland vegetation coverage, height and } \\
\text { grass productivity improved }\end{array}$ \\
\hline \multirow{4}{*}{$\begin{array}{l}\text { illegal } \\
\text { behavior(deduction } \\
\text { index) }\end{array}$} & Severe illegal behavior & / \\
\hline & Common illegal behavior & / \\
\hline & $\begin{array}{l}\text { Error rate of information } \\
\text { system data }\end{array}$ & Error rate of information system data \\
\hline & $\begin{array}{l}\text { Not consistent with the } \\
\text { approved implementation } \\
\text { plan }\end{array}$ & $\begin{array}{l}\text { Ratio of content not consistent with the } \\
\text { approved implementation plan }\end{array}$ \\
\hline
\end{tabular}

The current performance evaluation index system of the GECR policy mainly focuses on the implementation and management of the policy, to ensure the payment reached every household. Most of the indicators focus on the implementation process of the policy; the influence on grassland ecology is not fully evaluated. There is just one grassland ecological improvement index in the evaluation index system.

The GECR policy is related to the ecological protection of grassland covering almost all pastoral and agropastoral areas in China. It has not changed the mode of grassland use, only controlled the livestock number. We selected Xinjiang agro-pastoral area in China as case study, evaluated the performance of GECR from the aspects of 
ecological, economic and social benefits, analyzed problems of the policy design in agro-pastoral area, and provided policy suggestions for the improvement of the GECR Policy.

\section{MATERIALS AND METHODS}

\subsection{Study Area}

Agro-pastoral area extends from northeast to southwest in the north of China, covering 129,600 km2 (Hong \& Kamuna, 2008) accounting for $13.5 \%$ of China's land area. Xinjiang agro-pastoral area is located in the Yili Valley of Xinjiang. With local water and heat conditions, farmland was formed among grassland in agro-pastoral area (Zhao, Zhao, \& Zhang, 2002).

Xinjiang's Yili Valley agro-pastoral zone is stratified by elevation, transitioning from semi-arid agriculture at elevations below $1000 \mathrm{~m}$ to humid alpine meadow pasture above $1000 \mathrm{~m}$. Nileke County is located on the western slope of the Tianshan Mountains in the headwaters of the Yili River, in the Yili Kazak Autonomous Prefecture. Pastoralism and agriculture coexist in Nileke County, and the former plays a dominant role. Nileke County has a population of 189,000 and about one million ha of land, of which 678,000 ha are natural pasture and 38,000 ha is farmland. In 2015, net per capita income in Nileke County was 1,833 USD, around half the national average of 3,477 USD. As such, Nileke is a good example of an under-development rural county in China.

We selected two case study villages, $\mathrm{T}$ village and W village in Nileke County. In 2015, there were 423 households with 1,803 people in T village, all of them were pastoralists. Natural pasture area was about 10,667 ha, divided into three seasonal pasture areas: spring-autumn, summer, and winter pasture. Farmland area is about 720 ha. W village had 558 households with 2,273 people, 353 households were farmers and 205 households were pastoralists. Natural pasture area was about 9,333 ha, also divided into three seasonal pastures. Farmland area is about 504 ha. Livestock sale was the main income of pastoralists and farmers.

\subsection{Data Collection}

The GECR Policy was implemented since 2011. Annual data for the analysis were drawn primarily from government statistics from 2006 to 2015 . The time period was selected to include the 10 years period before and after of the policy implementation.

Field research was completed in 2015-2016, using semi-structured interviews with agro-pastoral households in $\mathrm{T}$ Village and $\mathrm{W}$ Village. Interviewees were selected by researchers with helping of local guides using a stratified sampling of income, age, and livelihood of pastoralists. 60 households in T Village and 83 households in W Village were interviewed, more than $15 \%$ of the total household number. Interview topics were mainly about family livestock grazing and farming production, living condition, and natural resource use before and after the ecological rewards were provided. Interviews focused on perceptions and opinions of environmental and social changes. Interviews collected both qualitative and quantitative data, including local situation and explanations of causation. Additional interviews of local government officials provided overall information on Nileke County.

In corresponding to the policy goal, this study selected 9 variable indicators to evaluate the performance of GECR (Table 2), including ecological, economic and social aspects. In ecological indicators, pasture vegetation net primary productivity(NPP) value reflected the grassland ecological condition. Livestock number in pastoral area and agriculture area reflected the changing trend of livestock number in case area. Overgrazing was the main cause of grassland degradation, thus reducing livestock number could release the grazing pressure of grassland. In economic indicators, net income per capita, loan and deposit amount under inflation rate correction were selected to indicate the change of household income level. In social indicators, the number of pastoral labor and agricultural 
labor reflected the population change of agricultural and livestock grazing production, while the number of employed labor (non-agro-pastoral labor) reflected the livelihood transition rate. The quantitative analysis data of the indicators were selected from the statistics of the county level, while the qualitative analysis data was from the field research data in household scale.

Table-2 Indicators to Evaluate the Performance of GECR.

\begin{tabular}{|c|c|c|c|c|c|}
\hline & Indicators & Mean & Maximum & Minimum & Standard Deviation \\
\hline \multirow[t]{3}{*}{ Ecology } & 1. Pasture vegetation NPP & 176.1 & 196 & 155 & 12.2 \\
\hline & $\begin{array}{l}\text { 2. Total Livestock number in } \\
\text { pastoral area( thousand sheep unit) }\end{array}$ & 1201.7 & 1348.7 & 1038.4 & 96.2 \\
\hline & $\begin{array}{l}\text { 3. Total Livestock number in } \\
\text { agriculture area( thousand sheep } \\
\text { unit) }\end{array}$ & 648.3 & 807.4 & 487.7 & 113.3 \\
\hline \multirow[t]{3}{*}{ Economy } & 4.Net income per capita(USD) & 6606.9 & 11419.8 & 2724.5 & 3213.2 \\
\hline & 5.Deposits per capita (USD) & 4297.5 & 7725.3 & 605 & 2934.6 \\
\hline & 6. Loans per capita (USD) & 3084.6 & 6704.8 & 633.9 & 1920.6 \\
\hline \multirow[t]{3}{*}{ Society } & 7. Pastoral labor & 16471.6 & 20804 & 11132 & 2802.6 \\
\hline & 8. Agricultural labor & 23411.1 & 25001 & 20975 & 1268.9 \\
\hline & $\begin{array}{l}9 . \quad \text { Employed labor(quit agro- } \\
\text { pastoral work) }\end{array}$ & 25508.5 & 35034 & 14210 & 6780.2 \\
\hline
\end{tabular}

\subsection{Analytical Method}

Combining quantitative analysis with qualitative analysis, this study described and analyzed the changes of grassland ecology, economic and social situation during 2006-2015, before and after the implementation of the GECR.

The quantitative analysis method was used to describe the annual change of 9 indicators. On this basis, the influence of GECR on grassland ecology, household income and livelihood transition after 2011 were further analyzed based on the fieldwork results. The data was collected in fieldwork by semi-structured household interviews, village leader interviews, villagers' representative group discussion, and grassland managers interview in county level.

\section{RESULTS}

\subsection{Ecological Performance}

The evaluation of the ecological performance was the most important part to measure the effectiveness of the policy. We selected the indicators from two aspects: grassland ecological recovery and achievement of livestock reduction.

\subsubsection{Grassland Ecological Recovery}

By comparing the annual changes of grassland vegetation NPP during 2006-2010 and 2011-2015, we found that the NPP value fluctuated in this period and was significantly correlated with annual precipitation in this area (correlation coefficient is 0.779). Moreover, NPP value did not increase since 2011 after the ecological rewards allocated to households even showed a downward trend during 2011-2015 (Figure 2). 
2006-2010

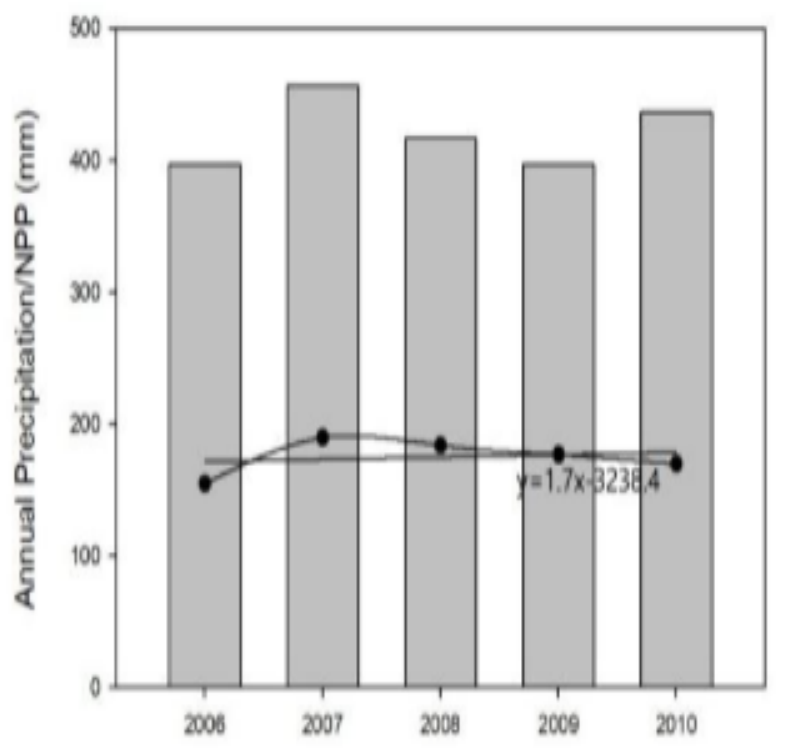

2011-2015

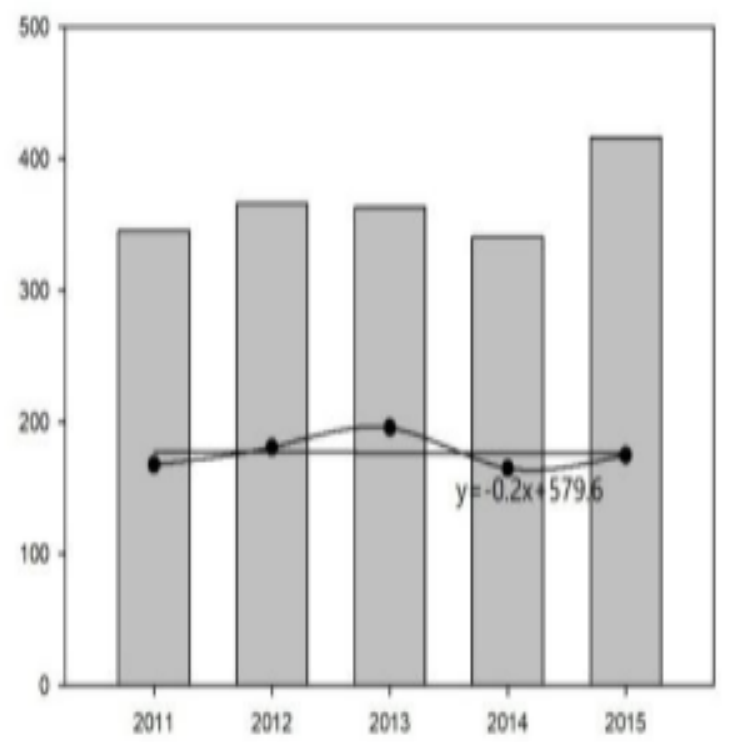

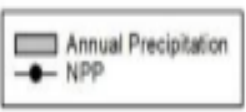

Figure-2. Annual Variations of NPP and Precipitation.

In field study, all interviewees believed that the grassland had been degraded since the 1990s, after the private use of grassland. The height and coverage of high-quality grass greatly reduced, and the amount of weeds and poisonous grass increased. $71 \%$ of the interviewees thought the most severe degradation grassland was the spring and autumn pasture which was near to the settlements and was used the longest period of time in one year. The main cause of grassland degradation was the limited move range of livestock, and a sharp growth of livestock eating and trampling the grass excessively after private use of grassland since 1984. From the perception of pastoralists, the amount of GECR was limited, and did not change the use pattern of the grassland. Thus the grassland ecological improvement effect of the policy was not obvious. Some pastoralists even called the ecological rewards as fence subsidy, namely the subsidies encouraged pastoralists to build fence on their own pasture, ensured that the pasture was used by their own household. In general, the GECR Policy had not played a role in protecting and restoring grassland ecology, the grassland degradation problem was still serious.

\subsubsection{Achievement of Livestock Reduction}

Livestock number in pastoral area showed a declining trend since 2011 after the implementation of the GECR (Figure 4), indicating that livestock reduction in pastoral areas had achieved some progress. However, according to the field study, farmers and pastoralists all lived in agro-pastoral area and generated a transaction relationship under the background of grassland private use and free market economy. Farmers raised livestock as investment and paid a herder to graze their livestock on the herder's pasture.

From the perspective of pastoralists, after the private use of grassland, household livestock grazing expenses (including seasonal migration and fencing) had increased along with the cost of living, meaning that it now takes far more animals to support a household than in the past. Households who had to sell their herds to pay for weddings or medical fees could rarely afford to rebuild their herds, forcing them to find other way of living such as the grazing transaction with farmer. 
From the perspective of farmers, livestock have become a common investment for farmers, who often fed the animals farm products and byproducts in the winter and $58 \%$ of the farmers in interview paid a herder to graze the herds on the herder's land in the rest of the year. The average price in 2015 was $2.4 \mathrm{USD} / \mathrm{month} / \mathrm{sheep}$ and 15.8 USD/month/cow or horse. Because of the low per-animal payment, relatively high costs associated with seasonal migrations, and high risk of having to repay the owners for sheep that are lost, die from disease, or are killed by wolves, herders normally have to take 300-500 sheep at a time just to turn a profit, far in excess of the livestock carrying capacity they could legally or sustainably graze on their pastures according to GECR Policy. Because most households could not afford to fence all their seasonal pastures, and mountain summer pastures were hard to fence, these farmers' herds ate up the grassland of other households, causing conflicts. With neither the traditional tribal structure nor the state-backed authority of the village leadership, the villages had no ability to sanction those members who overgraze their own or others' land.

The county level grassland management department was responsible for implementing the GECR, and supervising the livestock carrying capacity of each household. They set up checkpoint on the way to summer pasture to check the livestock number of each household, but the household number was too large in one county, they cannot realize daily supervision. What's more, we learned from interviews that herders could easily avoid confiscation of livestock or fines by borrowing others pasture certification to get a larger carrying capacity, or by asking relatives and friends who worked in local Grassland Management Department to help them to escape sanction. In the field survey, more than $90 \%$ of the pastoralists have confirmed that the main cause of grassland degradation was the excessive number of livestock on grassland, especially farmers' livestock, which obviously exceeds the authorized carrying capacity of pasture.

Statistics show that while the livestock number in pastoral area was decreasing, the livestock number in agricultural area had been increasing continuously during 2006-2015, and the pressure of grazing on grassland had not actually decreased (Figure 3). Therefore, although the herders' livestock number tended to decrease after the implementation of the policy, the livestock number of farmers kept increasing and the growth rate did not slow down after 2011. Farmers' livestock use grassland in spring, summer and autumn through grazing transaction with herders, resulting in excessive number of livestock carrying on grassland and leading to serious grassland degradation. The GECR policy in case area had not effectively achieved the goal of reducing livestock carrying capacity.

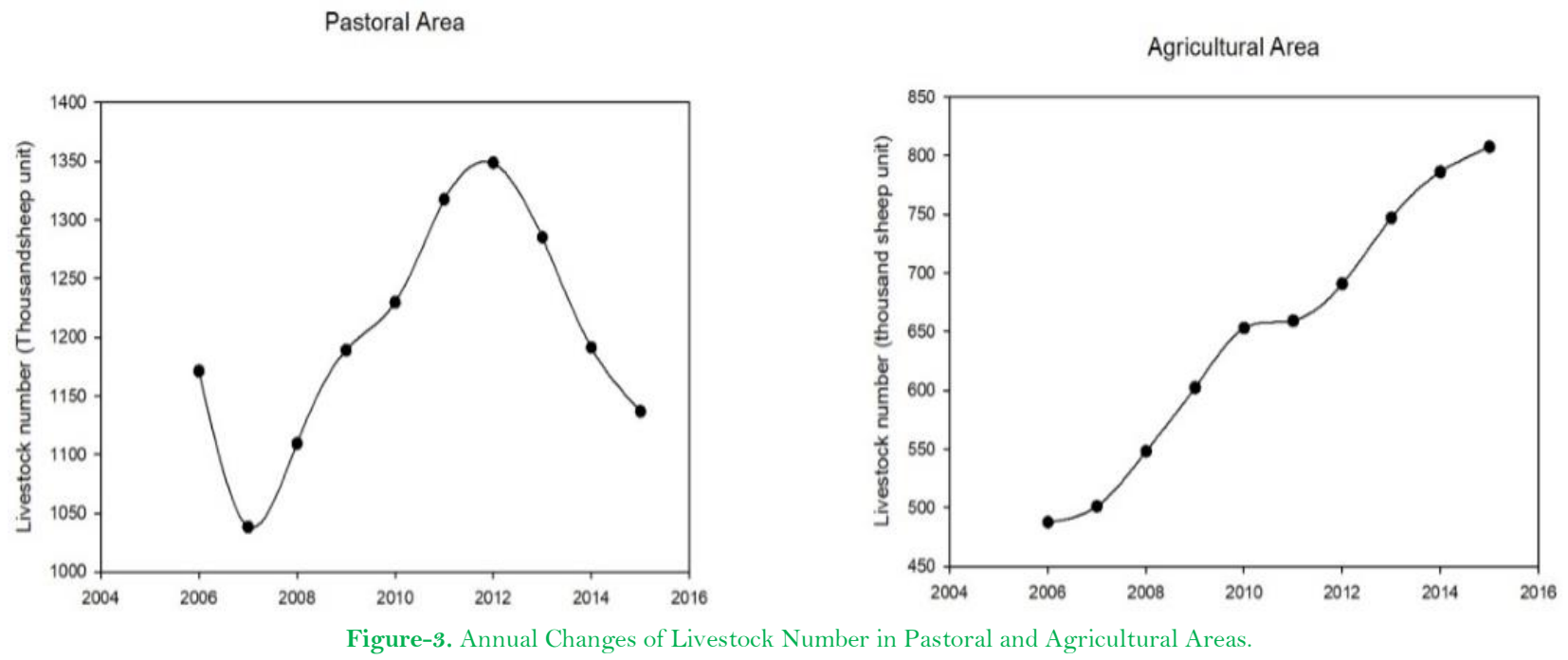




\subsection{Economic Performance}

The economic performance of GECR mainly measures whether the policy had an incentive effect on the income of pastoralists. From the annual variation trend of net income per capita, loans and deposits per capita, we found three indicators all showed increasing trend over 10 years before and after the implementation of the GECR, and they all showed a slightly slowed down growth rate from 2011 to 2015 Figure 4.

2006-2010

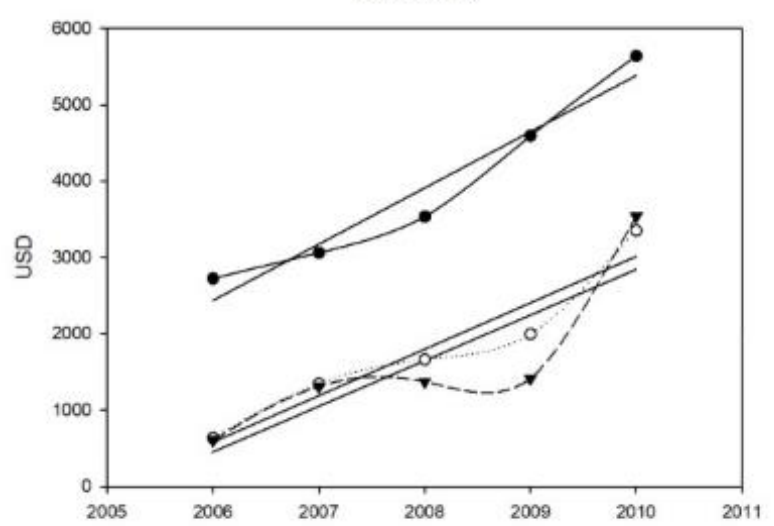

2011-2015

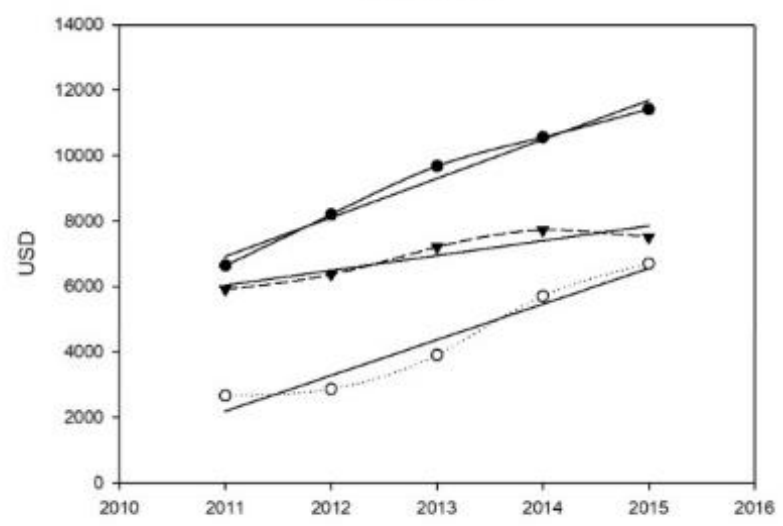

Figure-4. Annual changes in net income, loans and deposits.

Average household income increased significantly after the pasture and livestock were allocated to households in 1984. The main source of income for all households in the two villages was livestock sale. In 2015, livestock sale income accounted for $67 \%$ of the total income in case villages. Other sources of income included renting grazing land and labor, selling livestock products such as milk and wool, government subsidies, and wage work (Figure 5), and ecological subsidies only account for $3 \%$ of the total income. $52 \%$ of families had less than 50 livestock, and 3 households with no livestock rented out their pasture. Livestock number was limited by the availability of herding labor and financial problems that forced household selling all of their herds. Major household expenditures were living costs (52\%), including weddings and medical fees. Production costs accounted for $48 \%$ of household expenditures, and livestock costs such as buying forage and renting pasture were significantly greater than agricultural costs (Figure 5).

Most herders attributed increased income to higher livestock price under the influence of the market economy, and the payment for herders grazing farmers' livestock also contributed a lot on income. 50\% of herders believed that government settlement projects started in 2009 had improved their families' living standards, and the subsidies encouraged herders to build new houses and sheds in settlements. At the same time, many herder families began to borrow money from banks to pay for the construction of their houses. After settled down, the herders need to buy a large amount of forage in winter to feed animals in shelter, which was the main reason for the herders to take out loans every year. But all the herders agreed that the GECR standard was only 430 USD per family per year, which made little contribution to the increase of household income. 
Income

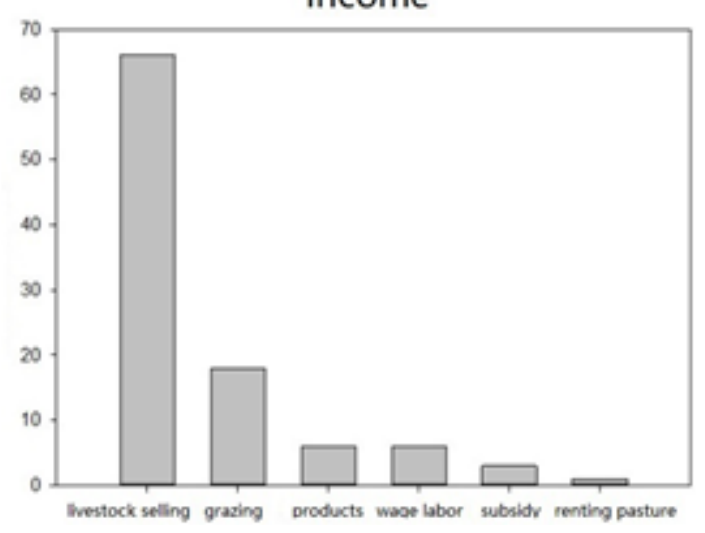

Expenditure

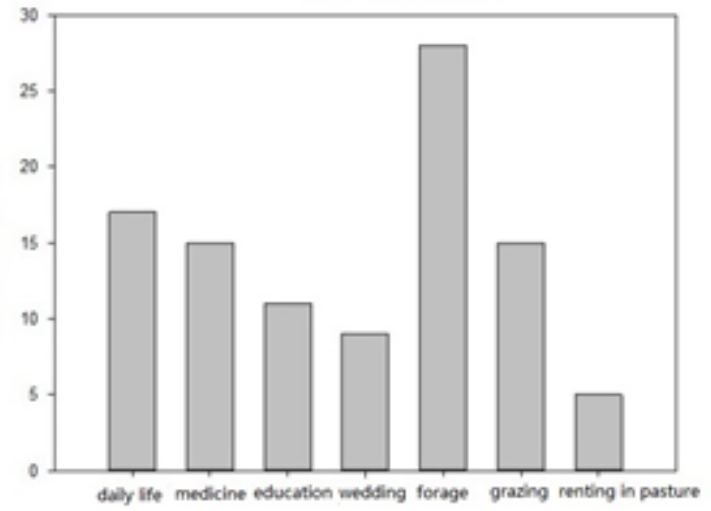

Figure-5. Income and Expenditure Composition of Case Villages.

\subsection{Social Performance}

The social performance was mainly used to measure whether the GECR had influence on encouraging pastoralists to change livestock production mode or find alternative livelihoods which led to livestock number reduction on grassland. Results showed that the three indicators all had increasing trend during 2006-2015. The number of pastoral labor and agricultural labor was relatively stable in 10 years, while the number of employed labor grew rapidly Figure 6.
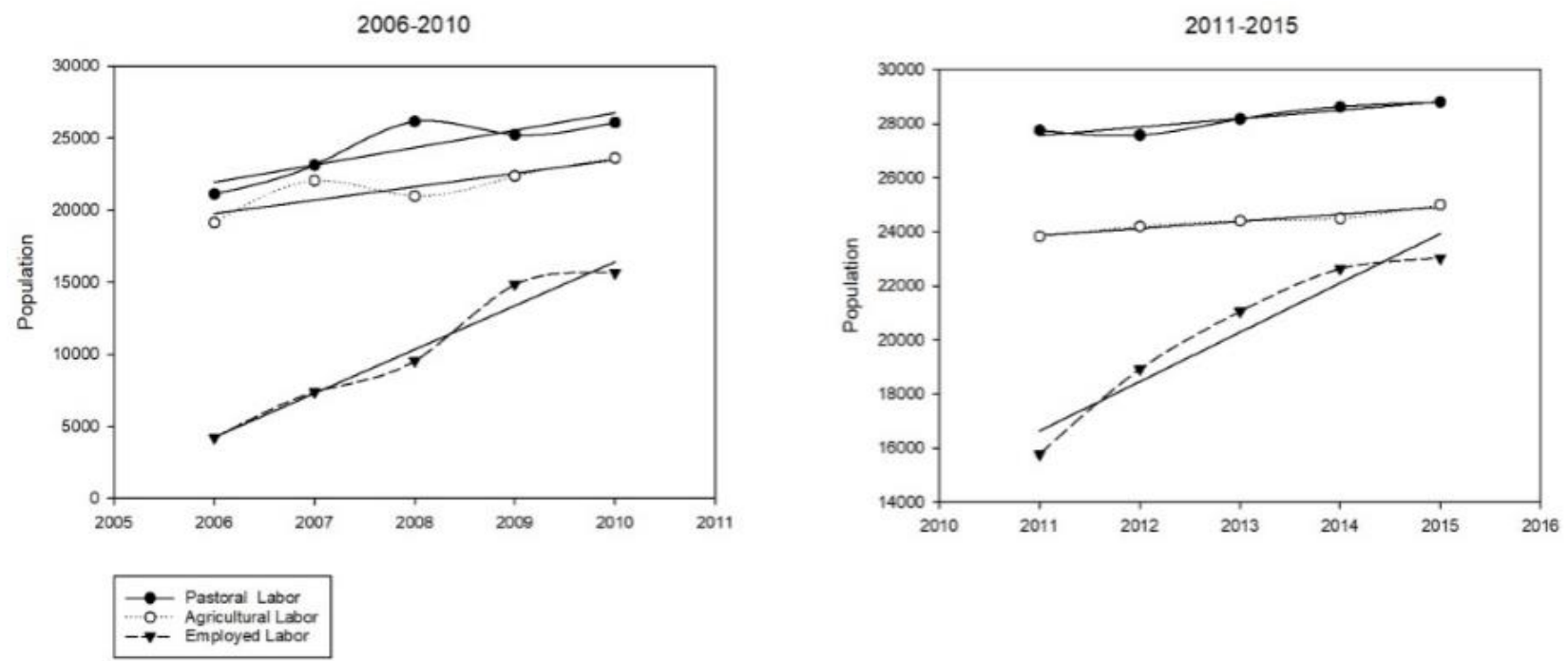

Figure-6. Annual Changes of Animal Husbandry, Agricultural and Migrant Labor Force.

On the one hand, although the number of employed workers increased rapidly, there was still a gap between the number of employed workers and the number of pastoral and agricultural labor. In case area, there was only a small amount of labor forces engaged in non-agro-pastoral activities. More than $80 \%$ of the herders who engaged in non-agro-pastoral work were young herders separated from large families without grassland. However, the households with larger pasture area could get more rewards, and they had no intention to give up livestock grazing. The overall economic development level in Western China was relatively low and the opportunities of employed working are limited. In addition, pastoral household need to do animal production work in household level, it required a lot of labor to complete work as grazing and animal transferring, which resulted in lack of extra employed labor in family. On the other hand, the GECR encouraged herders to change the production mode of 
animal husbandry, and promoted forage industry and intensive breeding. The measures of the local government in case area were helping herders build animal shelters and distributing free forage grass seeds for farmers to encourage them to plant forage on their fields as the supply of herders livestock feeding in shelters. The number of herders who raise their livestock in shelters in winter had increased. However, due to the high forage cost, no herders raised their livestock in shelters all year round. They still used grassland in other three seasons, and the animal production mode was still dominated by extensive grazing. At the same time, farmers received free forage grass seeds from government and changed to plant forage on farmland. But much of the forage production were used for winter forage supply for farmers own livestock. As a result, not only the herders' problem of the forage shortage in shelter animal husbandry were not solved, but also further expand the farmers livestock number by providing forage grass for farmers in winter. As a result, the extensive livestock production mode had not changed in case area. Moreover, the total number of livestock further increased, and the grassland was suffering a larger pressure to support exceeding number of livestock.

\section{DISCUSSIONS AND POLICY IMPLICATIONS}

It was not only the problem of low standard of compensation and rewards for the poor performance of the policy. From the results, grassland overgrazing problem was related to grassland private use and free market economy, and also related to the local human capital quality. Improving the compensation and rewards standard could increase pastoralists' income directly, but still could not reduce grassland degradation. Therefore, we put forward suggestions to improve the policy performance from four aspects: changing the design of the policy, establishing performance evaluation system, strengthening the supervision and punishment of grassland overgrazing and improving the local human capital quality.

Firstly, the central government needs to change the design of GECR Policy. Grassland ecological services were provided by the entire ecosystem, not by individual herders. However, the GECR were provided to individual herders according to the area of the pasture. The goal of the policy was to reduce livestock number, but there was no direct link between the rewards and herders' livestock reduction behavior. The mismatch between the rewards design and the policy goal led to the excess livestock number, resulting in the failure of the policy to achieve the goal of livestock number reduction and grassland protection. The leadership in village level or above should represent the value and services of grassland. Now the rewards mainly focused on the change of individual herder's grazing behavior, ignored the interaction mechanism of herder, livestock and grassland ecosystem. As a result, the government spent a large amount of money to reduce livestock, but cannot reach the policy goal. Therefore, GECR fund should be distributed to village collectives, who will coordinate the use of funds according to the livestock reduction reality, rather than subsidizing all herders.

Secondly, an effective performance evaluation system of GECR should be established. At present, the performance evaluation index system of the government mainly paid attention to whether the local grassland management offices had completed the tasks of rewards distribution, but ignored the evaluation of policy achievement. The core of GECR was grassland ecology protection. Therefore, it was necessary to design quantity and quality indicators reflecting the grassland ecological protection condition, and evaluating the livestock number control and grassland ecology. In addition, we should make efforts to raise income of herders and livelihood transition. An effective performance evaluation system should include the benefits of GECR on ecological, economic and social development. The results of performance evaluation were not only used to assess the work of the local government, but also to evaluate whether the policy had achieved the expected goal, and put forward suggestions for the improvement of policy design. Thirdly, supervision and punishment of overgrazing on grassland should be 
strengthen. GECR Policy was designed to provide subsidies to pastoral households who reduce their livestock number. Local Grassland Management Offices took the responsibilities to the supervision and punishment of overgrazing on grassland. However, it was not effective because the cost of breaking the rule is too low to be a warning, and many overgrazing herders escape punishment under poor supervision. Therefore, on the one hand, the way of punishment should be changed. The subsidy for grassland protection should not only include "rewards", but also include "sanction". The herders who violate the rules and overgrazing on grassland should be fined at least twice the rewards amount as punishment. On the other hand, the way of supervision should be changed. Local Grassland Management Offices could not do all the supervision work. The village collectives should play an important role in supervision. All the village members together formed effective supervision and punishment mechanism of livestock number control, every herder could participate in decision-making and enforcement process. In addition, as the role of the village collective was very important, it was also recommend forming cooperatives in agro-pastoral zone. Cooperative members could join their land and labor on the basis of voluntary mutual benefit and risk-sharing to meet the need for livestock production. In case study, farmer's livestock used grassland through the grazing transaction with herders, resulting in overgrazing. The main reason was herders only consider their own labor cost and ignored the cost of grassland resource loss in transaction price. If the transaction occurred between herder's cooperative and farmers, the value of the grassland could be considered in collective scale. When the transaction price increased, farmers reconsidered the cost and benefit of raising livestock and reduced the number of animals, while herders received the same benefit by grazing fewer animals. The goal of reducing the number of livestock on grassland achieved. Through the form of cooperatives, fragmented pasture resource could be integrated while the problem of pastoral labor shortage solved. Farmers and herders were encouraged to engage in other industries related to animal husbandry, in order to change the production structure that farmers and herders all depended on raising livestock. Finally, the measures to improve local human capital quality should be taken. It was necessary to enforce long-term policies and measures to gradually improve the quality of human capital of farmers and pastoralists. The quality and employability of the labor force in remote areas could be improved through early childhood intervention, basic education and technical training. Herders were encouraged to change their traditional production mode of grazing and engage in other industries related to animal husbandry. The local government should provide diversified job opportunities for young farmers and herders with strong abilities in order to change the industrial structure dominated by animal husbandry. In addition, grassland resource and labor could be integrated by establishing cooperatives to save human resource, encouraged more herders transfer to other employment.

\section{CONCLUSIONS}

During the implementation of the GECR Policy from 2011-2015, the livestock number of herders showed decreased tendency, but the livestock number of farmers still increased, and was taken to the pasture through the grazing transaction with herders. The total livestock number on grassland exceeds the carrying capacity, which led to grassland degradation. The ecological rewards received by a single household were relatively low and did not contribute much to the increase of the family income. Nor has the rewards had any real effect on transforming extensive livestock grazing to intensive animal husbandry, and encouraging herders to find alternative livelihoods. Through the performance evaluation, we found that the GECR Policy did not achieve significant benefits in ecology, economy and society in case area. The livestock carrying capacity control and grassland protection in agro-pastoral area are not only determined by the individual herders, but by the grassland, livestock and people, which constitute a complete social ecosystem. We should put grassland, livestock, herders and farmers as a whole, 
improve the design of the GECR policy, establish reasonable performance evaluation system, strengthen the supervision and punishment of grassland overgrazing, and improve local human capital quality to achieve the goal of protecting the grassland ecosystem and improving the living standard of farmers and herders through GECR Policy.

\section{REFERENCES}

Chen, H. (2013). Evaluation and expectation of grassland ecological protection subsidy policy by farmers and herders - based on the analysis of questionnaire survey data of woolly sheep farmers in 6 provinces and autonomous regions of Inner Mongolia. Journal of Agricultural Economics and Theory, 28(5), 73-81.

Dong, Z., \& Liu, X. (2009). Status and cause analysis of grassland degradation in Xinjiang. Journal of Hebei Agricultural Sciences, $13(4), 89-96$.

Fan, S., Ma, L., \& Yin, Z. (2008). Research on performance evaluation of ecological governance policy based on farmers. Arid Region Geography, 31(4), 572-579.

Gu, Y., \& Li, W. (2012). Study on the influence of grazing ban policy on pasture quality-based on the analysis of pastoral scale. Journal of Peking University: Natural Science, 49(2), 288-296.

Hong, T., \& Kamuna, J. (2008). Brief history of kazak (pp. 38-51). China: Nationalities Press.

Hu, Z., Liu, D., \& Jin, L. (2016). Grassland ecological compensation: Ecological performance, income impact and policy satisfaction. China Population, Resources and Environment, 35(1), 165-176.

Jin, H. (2015). Impact of grassland ecological protection compensation reward on herders and measures. China Livestock and Poultry Industry, $11(2), 48$.

Li, W., \& Li, Y. (2012). Managing rangeland as a complex system: How government interventions decouple social systems from ecological systems. Ecology and Society, 17(1), 1-9. Available at: https://doi.org/10.5751/es-04531-170109.

Li, X. (2006). Empirical study on the impact of returning grazing land to grassland project on herders' income in Inner Mongolia. Journal of Agro-Technical Economy, 13(3), 63-68.

Li, P., Sun, X., \& Zhang, J. (2017). Policy issues and suggestions on grassland ecological compensation. Chinese Journal of Frassland Science, 39(1), 1-6.

Li, Y., Gong, B., \& Li, W. (2014). A review of China's rangeland management policies (pp. 28). IIED Country Report: London, UK.

Ma, Y., Lu, Y., \& Xing, Y. (2006). Behavior response of farmers to the policy of banning grazing and its influencing factors - a case study of Zelle county, Xinjiang. Arid Region Geography, 29(6), 903-908.

Song, N., Zhang, F., Li, B., Chen, H., Yao, H., \& Cao, L. (2004). Prohibiting graze policy and its effect. Journal of Natural Resources, 19(3), 316-323.

Zhang, Q. (2016). Analysis on the economic incentive effect of grassland living subsidy system Gansu Social Sciences, 5(1), 234238.

Zhao, H., Zhao, X., \& Zhang, T. (2002). Geographical definition and ecological problems of the Northern farming-pastoral ecotone. Advances in Earth Sciences, 17(5), 739-746.

Online Science Publishing is not responsible or answerable for any loss, damage or liability, etc. caused in relation to/arising out of the use of the content. Any queries should be directed to the corresponding author of the article. 